\title{
Aleksandra Kusztykiewicz
}

\section{Dyplomacja cyfrowa - nowa forma polityki zagranicznej Unii Europejskiej}

\section{Streszczenie}

Rozwój społeczeństwa informacyjnego zainicjował potrzebę stworzenia nowych instrumentów, za pomocą których władze mogą docierać do obywateli, dlatego cyberprzestrzeń stała się w ostatnim czasie miejscem aktywności wielu podmiotów, w tym państw oraz organizacji międzynarodowych (również Unii Europejskiej). Skutkiem tego zjawiska jest powstanie tak zwanej dyplomacji cyfrowej jako nowej jakości w miękkiej dyplomacji UE. Dyplomacja UE używa obecnie wielu e-instrumentów, m.in. Facebooka, Myspacéa, Daily Motion, YouTube’a itp. Są to bardzo dobre narzędzia służące poprawianiu i ocieplaniu wizerunku Unii na arenie międzynarodowej. Ten rodzaj dyplomacji ukształtował się dopiero na początku XXI w. i ma przed sobą obiecującą perspektywę rozwoju, dlatego warto się zastanowić, w jakim kierunku ewolucja ta powinna podążać. Dyplomacja cyfrowa jest de facto odpowiedzią na problem komunikacji Unii ze światem zewnętrznym oraz na zjawisko rosnącej liczby użytkowników Internetu.

Słowa kluczowe: dyplomacja, cyberprzestrzeń, Unia Europejska, społeczeństwo informacyjne, dyplomacja cyfrowa, miękka dyplomacja Unii Europejskiej

\section{Digital Diplomacy - a new form of foreign policy of the European Union}

\begin{abstract}
The development of the information society has initiated the need for creating new instruments with the help of which the authorities can reach out to citizens. Therefore, cyberspace has recently become a place of activity of a number of entities including state and international organizations (together with the European Union). The result of this phenomenon is the creation of the so-called digital diplomacy as new quality in the soft diplomacy of the EU. The EU diplomacy currently uses a number of e-tools, among others, Facebook, MySpace, Daily Motion, YouTube, etc. These tools are a very good method to improve and warm up the image of the Union in the international arena. This kind of diplomacy was only formed at the beginning of the twenty-first century and
\end{abstract}


has a great prospect of development, thus, it is worth considering in which direction its evolution should follow. Digital diplomacy is a de facto response to the problem of the EU communication with the outside world and the growing number of Internet users.

Keywords: diplomacy, cyberspace, the European Union, the information society, digital diplomacy, soft diplomacy of the European Union

\section{Współczesna dyplomacja Unii Europejskiej}

„Świat zmienił się w niezwykle destrukcyjny sposób, dyplomaci muszą podążać z duchem czasów, inaczej staną się mniej użyteczni i wpływowi”' - tak o współczesnej dyplomacji wyrażał się doradca w Biurze Sekretarza Stanu USA Hilary Clinton Alec Ross. Twierdzenie to $\mathrm{z}$ całą pewnością jest prawdziwe, ale czy zasadne jest przypisywanie obecnym zmianom jedynie negatywnego charakteru?

Pojęcie dyplomacji jako takiej od wieków było utożsamiane jedynie z nawiązywaniem oraz utrzymywaniem stosunków między państwami. Współcześnie tradycyjne kontakty dyplomatyczne zaczynają tracić swoją pierwotną funkcję, ustępując miejsca nowym narzędziom. Informacje, jakie zdobywali ambasadorowie, nie są już tak ważne w nawiązywaniu kontaktów między państwami, jak to było jeszcze kilka lat temu. Wraz z rozwojem stosunków międzynarodowych zaczęły się pojawiać nowe drogi komunikacji, a także nowe podmioty relacji dyplomatycznych. Cechą charakterystyczną nowego ładu jest współczesna tendencja do występowania trzech nowych zjawisk: po pierwsze, zmiany organizowania się podmiotów w stosunkach międzynarodowych innych niż państwa, po drugie, zmiany parametrów potęgi i siły państwa w tych stosunkach oraz po trzecie, zmiana metod prowadzenia dyplomacji ${ }^{2}$.

Unia Europejska jako twór stosunkowo młody ma dużo mniejsze doświadczenie w tradycyjnie rozumianej dyplomacji niż wchodzące w jej skład państwa członkowskie. W związku z tym narzędzia, za pomocą których prowadzi ona politykę zagraniczną, również są w wielu wypadkach niekonwencjonalne. Dotychczasową politykę zagraniczną Unii Europejskiej charakteryzowała wielość instytucji, a także instrumentów działania. Pewnego rodzaju przełomem stał się traktat lizboński z 2009 r., który wprowadził w UE nowe możliwości działania w zakresie dyplomacji europejskiej, powołując do życia Europejską Służbę Działań Zewnętrznych. Jest ona organem, który

1 Digital Diplomacy for the 21st Century - A Transatlantic Perspective http://www.epc.eu/prog_details. php?cat_id=6\&pub_id=2790\&prog_id=3, dostęp: 05.01.2015.

2 B. Piskorska, Dyplomacja cyfrowa: instrument miękkiej sity Unii Europejskiej w stosunkach międzynarodowych s. 105, w: Dyplomacja cyfrowa jako instrument polityki zagranicznej XXI wieku, Lublin 2014. 
wspomaga Wysokiego przedstawiciela ds. polityki zagranicznej i bezpieczeństwo jego działań. ESDZ jest ponadto zobowiązana do udzielania pomocy i wsparcia wszystkim instytucjom realizującym swoje zadania w obszarze zewnętrznych stosunków Unii. Dotyczy to zwłaszcza Przewodniczącego Rady Europejskiej, Przewodniczącego Komisji Europejskiej i szefów poszczególnych komisji oraz Parlamentu Europejskiego ${ }^{3}$. W skład ESDZ wchodzą powoływani przez Wysokiego Przedstawiciela urzędnicy i inni pracownicy Unii Europejskiej, w tym pracownicy ze służb dyplomatycznych państw członkowskich mianowani na czas określony ${ }^{4}$.

W związku z rozwojem UE jej efektywność w dziedzinie polityki zagranicznej wymaga nowych narzędzi ${ }^{5}$. Jednym z takich rozwiązań jest dyplomacja cyfrowa, która jawi się jako instrument polityki zagranicznej XXI wieku.

Rozwój nowych technologii oprócz tego, że wniósł nową jakość do życia codziennego przeciętnych Europejczyków, stworzył również nowe narzędzie w stosunkach międzynarodowych, które określa się mianem e-dyplomacji. Komunikowanie się za pomocą Internetu oraz aplikacji mobilnych to chleb powszedni współczesnych instytucji. Taki stan rzeczy prowadzi do rozwoju nowych zjawisk, a także przenoszenia niektórych obszarów życia do sieci. To, co jeszcze do niedawna było niewyobrażalne dla większości europejskich dyplomatów, stało się rzeczywistością. Okazało się bowiem, że możliwe jest prowadzenie skutecznej dyplomacji za pomocą mediów społecznościowych oraz innych kanałów internetowych. Celem tego opracowania będzie przedstawienie sposobów prowadzenia dyplomacji cyfrowej przez Unię Europejską oraz analiza ich skuteczności.

$\mathrm{W}$ celu analizy wyżej przedstawionej problematyki zasadne jest udzielenie odpowiedzi na pytania: Czy dyplomacja europejska może zostać wzmocniona za pomocą cyberprzestrzeni? Czy Unia Europejska dysponuje odpowiednim zapleczem prawnym oraz potencjałem, dzięki którym media społecznościowe mogą stać się narzędziem działań dyplomatycznych? Jakie korzyści i zagrożenia niesie ze sobą e-dyplomacja i czy Unia Europejska jest zdolna do wykorzystania potencjału, jaki mają narzędzia e-partycypacji? Czy tradycyjna dyplomacja może zostać zastąpiona działaniami w Internecie? Czy postęp technologiczny wyklucza potrzebę misji dyplomatycznych?

\footnotetext{
http://www.uniaeuropejska.org/europejska-sluzba-dzialan-zewnetrznych, dostęp 7.01.2015.

Ibidem.

J. Czaputowicz, Polityka zagraniczna i dyplomacja Unii Europejskiej, Warszawa 2010, s. 5.
} 


\section{Dyplomacja cyfrowa a soft power}

E-dyplomacja zaliczana jest do jednego z głównych narzędzi tak zwanej dyplomacji publicznej, która w literaturze przedmiotu rozumiana jest jako sposób, w jaki rząd i osoby prawne [...] oraz grupy bezpośrednio lub pośrednio wpływają na te postawy i przekonania opinii publicznej, które mają bezpośrednie przełożenie na decyzje dotyczące polityki zagranicznej drugiego rządu ${ }^{6}$. Definicja ta wymaga jednak doprecyzowania, jeżeli chodzi o podmioty mogące podejmować decyzję. Oprócz rządów mogą to być również podmioty transgraniczne oraz organizacje międzynarodowe, w tym również eksponowana w niniejszym opracowaniu Unia Europejska. Owa dyplomacja publiczna jest jednym z narzędzi tak zwanej miękkiej siły. Określona przez J. Nye’a soft power jest siłą łagodności, przekonywania poprzez odwoływanie się do multilateralizmu i prawa międzynarodowego, współpracy gospodarczej, atrakcyjności kulturowej oraz wspólnych wartości w celu kształtowania preferencji pozostałych uczestników ładu światowego ${ }^{7}$. Natura miękkiej siły polega jednak na tym, że rządy, społeczeństwa i konkretni obywatele innych państw (świadomie lub nie, ale zawsze dobrowolnie) zaczynają utożsamiać własne potrzeby $\mathrm{z}$ interesem danego państwa czy organizacji ${ }^{8}$. Wszystkie te kwestie wpływają na fakt, że określenie efektywności miękkiej siły jest bardzo trudne, ponieważ jest ona zdeterminowana przez wiele czynników, do których można zaliczyć m.in. nowoczesne środki komunikacji oraz istotę dyplomacji publicznej - jako narzędzia wywierania wpływu na opinię masową poprzez mass media9.

Miękka siła jest jednym z najważniejszych instrumentów realizacji polityki zagranicznej państw w XXI wieku. Stanowi niezwykle efektywne narzędzie, pomagające zdobywać punkty tam, gdzie tradycyjne metody nawet najbardziej doświadczonej i subtelnej dyplomacji nie przynoszą i z założenia nie mogą przynieść rezultatów ${ }^{10}$. Okazją do wykorzystania zasobów miękkiej siły państw członkowskich na forum Unii Europejskiej jest sprawowanie przez nie półrocznej prezydencji w Radzie UE ${ }^{11}$. Jest

6 B. Signitzer, T. Coombs, Public Relations and Public Diplomacy: Conceptual Convergence, "Public Relations Review", cyt. za: E Gilboa, Dyplomacja w epoce informacji, w: Dyplomacja publiczna, red. B. Ociepka, Wrocław 2008, s. 40.

7 B. Piskorska, Dyplomacja cyfrowa: instrument miękkiej sity Unii Europejskiej w stosunkach międzynarodowych, w: Dyplomacja cyfrowa jako instrument polityki zagranicznej XXI wieku, Lublin 2014. s. 110.

8 www.new.org.pl/1157, post.html, dostęp: 5.01.2015.

9 N. Snow, Rethinking Public Diplomacy, w: N. Snow, P.M. Taylor, Routledge Handbook of Public Diplomacy, New York 2009, s. 3-10.

10 www.new.org.pl/1157, post.html, dostęp: 5.01.2015.

11 B. Piskorska, Dyplomacja cyfrowa: instrument miękkiej sity Unii Europejskiej w stosunkach międzynarodowych, s. 112. 
ona znakomitą okazją do zaprezentowania się państwa i wykazania jego umiejętności dyplomatycznych, ale również organizacyjnych.

Rozwój mediów społecznościowych na niewyobrażalną dotąd skalę spowodował potrzebę angażowania się $\mathrm{w}$ tych obszarach również polityków, ekonomistów czy dyplomatów. W ten sposób stworzono nową jakość w dyplomacji, którą nazwano cyberdyplomacją, dyplomacją cyfrową, e-dyplomacją (pojęcia te można stosować wymiennie). Zgodnie z wyżej przedstawioną definicją miękkiej siły, dyplomację cyfrową można określać mianem instrumentu soft power, który stosowany jest we współczesnych stosunkach międzynarodowych. Powstanie tego typu zjawisk jest wynikiem procesów globalizacji, które prowadzą do unifikacji pewnych standardów i norm.

\section{Cyberprzestrzeń jako obszar funkcjonowania Unii Europejskiej}

W jednym ze swoich wystąpień ówczesny szef MSZ-etu R. Sikorski powiedział, że w Brukseli politycy potrafią podejmować naprawdę europejskie decyzje z myślą o wspólnym dobru. Ale gdy wracają do siebie, z obywatelami rozmawiają wyłącznie w kategoriach interesów narodowych ${ }^{12}$. Dzieje się tak głównie z dwóch powodów, po pierwsze obywatele państw członkowskich nie utożsamiają się wprost z Unią Europejską, co bardzo dobrze pokazują statystyki. Znakomita większość obywateli Polski w pierwszej kolejności określa siebie jako Polaka, dopiero później jako Europejczyka. Kolejnym powodem, dla którego mieszkańcy państw członkowskich stawiają UE na drugim miejscu są niedostateczne działania ze strony samej Unii, która przeciętnemu Kowalskiemu kojarzy się jedynie z funduszami unijnymi. W związku z tym UE musi szukać nowych obszarów, w których mogłaby wprowadzić odpowiednie narzędzia do zmiany własnego wizerunku. Cel ten można zrealizować przy pomocy Internetu, oczywiście dobierając do tego odpowiednie metody.

„Bez wątpienia Internet oferuje wiele możliwości. Pomaga rozwijać demokrację i sprawia, że ludzie są bardziej aktywni w tworzeniu decyzji bezpośrednio wpływających na ich życie"13 - tak zalety sieci przedstawiał sam Michaił Gorbaczow. Skoro cyberprzestrzeń jest pomocna w tak wielu obszarach, należy się przyjrzeć, jak jej potencjał wykorzystuje Unia Europejska i czy europejscy urzędnicy zdają sobie sprawę, jak wiele korzyści może przynieść racjonalna strategia wobec sieci

12 http://m.wyborcza.pl/wyborcza/1,105226,12691307, Sikorski_dla_Gazety__Mamy_Unie_teraz_ trzeba_stworzyc.html?as=2, dostęp: 5.01.2015.

13 http://www.potencjalinternetu.pl/, dostęp: 8.01.2015. 
i czy uwzględniają przy tym rosnącą liczbę jej użytkowników. Jak pokazują badania Eurostatu z 2014 r., użytkowanie Internetu stało się bardzo rozpowszechnione wśród Europejczyków, coraz więcej ludzi jest jego beneficjentami, w 2014 r. prawie dwie trzecie (65 proc.) osób w wieku 16-74 lata w EU-28 używało Internetu codziennie, dla porównania w $2006 \mathrm{r}$. odsetek ten wynosił jedynie 31 proc. W tym samym czasie zaledwie 18 proc. mieszkańców Europy deklarowało, że nigdy nie używało Internetu (w 2006 r. było to ok. 43 proc.) ${ }^{14}$. Pojawienie się tak zwanych dysków sieciowych w ostatnich latach poprawiło atrakcyjność sieci. Umożliwiają one przechowywanie plików w chmurze, a dzięki specjalnym aplikacjom synchronizację danych na komputer i urządzenia mobilne, co zapewnia dostęp do plików z każdego miejsca na Ziemi ${ }^{15}$. Ta stosunkowo nowa forma usługi internetowej rozwinęła się w ostatnich latach na bardzo dużą skalę. W 2014 r. 21 proc. osób w wieku 16-74 lata w EU-28 używało Internetu do tworzenia, magazynowania oraz zapisania plików. Jak można było się spodziewać, największy odsetek osób korzystających z tego typu narzędzi w 2014 r. został zanotowany wśród młodych ludzi (35 proc. w grupie wiekowej 16-24 lata) ${ }^{16}$.

Przywołane badania pokazują jednoznacznie, że liczba użytkowników Internetu wzrasta w zawrotnym tempie, co umożliwia UE (ale też innym podmiotom) docieranie do szerszej grupy odbiorców. Jakie działania w sieci prowadzi Unia Europejska? Kto w jej imieniu prowadzi takie działania? Najważniejsze (i najbardziej znane) instytucje UE, a więc Parlament Europejski, Komisja Europejska oraz Rada Europejska oprócz oficjalnych stron internetowych prowadzą swoją działalność również w mediach społecznościowych. A. Kaplan i M. Haenlein definiują media społecznościowe jako grupę aplikacji stworzonych dzięki rozwiązaniom internetowym opartym na ideologicznych i technologicznych podstawach Web 2.0, które umożliwiają tworzenie i wymianę wygenerowanych przez użytkowników treści ${ }^{17}$. Web 2.0 - określenie użyte po raz pierwszy w 2004 r. - stanowi dla mediów społecznościowych fundament technologiczny, który umożliwia ich powstanie.

Dyplomacja UE używa obecnie wielu e-instrumentów, m.in. Facebooka, Myspace’a, Daily Motion, YouTube’a itp. Są to bardzo dobre narzędzia służące poprawianiu i ocieplaniu wizerunku Unii na arenie międzynarodowej. Tematyka aktywności UE w Internecie zostanie szerzej poruszona w kolejnym rozdziale.

14 Ibidem, s. 1.

15 http://www.pcformat.pl/Pliki-w-chmurze,a,2539, dostęp: 6.01.2015.

16 Internet Usage..., op.cit, s. 1.

17 A. Kaplan, M. Haenlein, Users of the World, Unite! The Challenges and Opportunities of Social Media, "Business Horizons" 2010, Vol. 53, No. 1, s. 59-68. 


\section{Dyplomacja cyfrowa Unii Europejskiej}

W literaturze dotyczącej szeroko pojętej dyplomacji poświęca się coraz więcej uwagi na przedstawienie rozmaitych typologii, które pojawiają się w ramach tego pojęcia. Autorzy dokonują rozróżnienia, biorąc pod uwagę kryteria związane z podmiotami, które prowadzą ową dyplomację, a także sposobami jej zarządzania. Bardzo mało miejsca poświęca się jednak działaniom (poszczególnych państw oraz innych podmiotów stosunków międzynarodowych) w Internecie, które zaczęto określać mianem dyplomacji cyfrowej, rozumianej jako współcześnie najbardziej powszechne narzędzie komunikacji w XXI wieku. Nowoczesne środki komunikacji zmieniają istniejącą hierarchię i rozkład sił pomiędzy globalnymi podmiotami dyplomatycznymi. Państwo traci kontrolę nad przepływem informacji na rzecz innych instytucji, a wraz ze wzrostem dostępności informacji rozszerza się także krąg zaangażowanych i zainteresowanych prowadzeniem działań dyplomatycznych ${ }^{18}$. Dzięki temu kształtuje się nowa przestrzeń dla dyplomatycznych działań UE.

Zastosowanie dyplomacji cyfrowej w polityce zagranicznej Unii Europejskiej jest łatwiejsze niż wykorzystanie tego narzędzia przez państwa. Dzieje się tak, ponieważ UE jest tworem stosunkowo młodym, który nie ukształtował własnych kanałów dyplomatycznych. Z kolei państwa, które od zawsze kładły nacisk na tradycyjną dyplomację, i dla których zgodnie z twierdzeniem A. Derudy ${ }^{19}$ ", uścisk dłoni pozostaje nadal najważniejszym narzędziem dyplomacji” mają problem z wdrożeniem nowoczesnych narzędzi w relacjach z innymi podmiotami stosunków międzynarodowych. Kolejną ważną kwestią jest także fakt, że w wypadku państw powszechnie wiadomo, kto reprezentuje je w kontaktach poza granicami i kto dokonuje „uścisków dłoni”, natomiast jeżeli chodzi o UE - nie jest już to takie oczywiste.

Jeżeli weźmiemy pod uwagę różne instytucje UE, intensywność ich działań w dziedzinie dyplomacji cyfrowej jest bardzo zróżnicowana. Nie zmienia to jednak faktu, że poprzez instrumenty cyberdyplomacji UE stara się samodzielnie poszukiwać nowych dróg poprawy wizerunku i skuteczności służby zagranicznej ${ }^{20}$. Co więcej, polityka zagraniczna może zajmować się tematyką, która z punktu widzenia przeciętnego Europejczyka jest atrakcyjna. Podejmując próbę określenia charakteru dyplomacji

18 B. Surmacz, Wpływ nowych technologii na funkcje współczesnej dyplomacji, w: Dyplomacja cyfrowa jako instrument polityki zagranicznej XXI wieku, Lublin 2014. s. 19.

19 A. Deruda - z pochodzenia Włoch, ekspert ds. komunikacji, z piętnastoletnim, międzynarodowym doświadczeniem z zakresu cyfrowej dyplomacji.

20 B. Piskorska, Dyplomacja cyfrowa: instrument miękkiej sity Unii Europejskiej w stosunkach międzynarodowych, s. 127. 
cyfrowej, można użyć trzech przymiotników: szybka, wizualna, interaktywna. I właśnie ta ostatnia cecha sprawia, że Unia Europejska może wspólnie z jej obywatelami ujednolicać kształt polityki zagranicznej, kładąc tym samym nacisk na najbardziej ważkie problemy.

Dla niektórych pewnym zaskoczeniem może być fakt, że e-dyplomacja wymaga znacznie więcej od europejskich dyplomatów niż jej tradycyjna odmiana. Stwierdzenie to wydawać by się mogło absurdalne, ponieważ przywykliśmy do tego, iż Internet pomaga i ułatwia wiele spraw. Należy jednak zwrócić uwagę, że spostrzeżenia polityków umieszczane na portalach społecznościowych nie są elementem dyplomacji cyfrowej. Dzieje się tak, ponieważ często ukazują one jedynie kwestie związane z życiem osobistym dyplomatów, natomiast nie ma w nich otwarcia się na dialog, nie przedstawiają one również założeń polityki zagranicznej. Dlatego też politycy, chcąc realizować założenia e-dyplomacji, powinni być szczególnie skrupulatni i ostrożni. W dużej mierze ów interaktywny charakter nowej dyplomacji zależy od dojrzałości zarówno elit politycznych, jak i obywateli.

\section{E-dyplomacja - regulacje prawne}

W kwestii e-dyplomacji nie ma żadnych regulacji międzynarodowych, które rozwiązywałyby problemy pojawiające się na tej płaszczyźnie. O ile stworzono konwencję o stosunkach dyplomatycznych i konsularnych, o tyle w wypadku Internetu, który daje nowy wymiar dyplomacji, takich regulacji nie ma. Ten stan rzeczy prowadzi do tego, iż przedstawiciele państw poruszają się głównie w obrębie zwyczajów, a nie określonych prawem przepisów. Jak pisał Andrzej Frycz Modrzewski, „bez praw nie może być prawdziwej wolności”21, dlatego prawne uregulowanie tej tematyki powinno być priorytetem na przyszłość.

W dotychczas stworzonych regulacjach prawnych Unii Europejskiej w tej dziedzinie na szczególną uwagę zasługują:

- Strategia Unii na rzecz dyplomacji cyfrowej w polityce zagranicznej (Digital Freedom Strategy in the EU's foreign policy),

- Europejska Agenda Cyfrowa (Digital Agenda UE).

Strategia Unii na rzecz dyplomacji cyfrowej w polityce zagranicznej została zatwierdzona przez Parlament Europejski w listopadzie 2012 r. Wprowadzając ją, UE postanowiła wyjść naprzeciw oczekiwaniom niektórych państw członkowskich. W związku z tym, iż niektóre kraje uznały dostęp wszystkich obywateli do Internetu

${ }_{21}$ I. Chrzanowski, Historia literatury niepodległej Polski, Warszawa 1922, s. 121. 
za prawo podstawowe, należało w ramach państw wchodzących w skład Unii Europejskiej utworzyć wspólny plan działania. Komisja Europejska podkreśliła, że w świecie, gdzie globalne powiązania wpływają również na kształt polityki zagranicznej, UE powinna posiadać strategię odnoszącą się do wykorzystania nowych technologii w jej działaniach z pomiotami zewnętrznymi. Przedstawiciele UE przyznali, iż przesadne uregulowanie (co jest cechą charakterystyczną legislacji UE) zaszkodziłoby potencjałowi, jaki niesie ze sobą otwarty charakter Internetu. Jednak w niektórych obszarach przepisy prawa należy zmodyfikować tak, aby rozwój technologiczny miał stosowny nadzór demokratyczny. Ponadto, w Strategii Unii na rzecz dyplomacji cyfrowej w polityce zagranicznej stwierdzono, iż UE powinna dokonać wszelkich starań, aby stworzyć bardziej skuteczną i efektywną politykę rozwojową, która uwzględniałaby technologie informacyjno-komunikacyjne (TIK).

W Strategii Unii na rzecz dyplomacji cyfrowej w polityce zagranicznej uwzględniono również kwestię praw człowieka, podkreślając, iż współcześnie walka o nie została przeniesiona do Internetu, a więzienia są coraz bardziej zaludnione przez dysydentów, których internetowe wypowiedzi władze wykorzystały przeciw nim ${ }^{22}$. Politycy w UE podkreślili także, że współcześnie walka reżimów autorytarnych coraz częściej obejmuje swoim zasięgiem również TIK. Zgodnie z europejskimi założeniami propagowanie, a także ochrona praw człowieka powinny polegać m.in. na unikaniu lub zapobieganiu atakom cybernetycznym przez poszczególne rządy. Dyplomaci w UE zdali sobie sprawę, że szeroko rozumiana cyberprzestrzeń może być nie tylko narzędziem, dzięki któremu można komunikować się ze światem, ale także stanowić duże zagrożenie (np. ataki hakerskie).

Unia Europejska bardzo aktywnie wspiera rozwój społeczeństwa informacyjnego na kilku płaszczyznach. W pierwszej kolejności stara się rozpowszechnić i ułatwić dostęp klientów do tzw. ekonomii cyfrowej w ramach poprawy działania Jednolitego Rynku UE do 2015 r. ${ }^{23}$. Przyjęta Europejska Agenda Cyfrowa bardzo szeroko i skrupulatnie traktuje o społeczeństwie informacyjnym - jest również jednym z siedmiu projektów przewodnich strategii Europa $2020^{24}$.

Zgodnie z informacjami przekazanymi przez UE, ogólnym celem agendy cyfrowej jest uzyskanie trwałych korzyści ekonomicznych i społecznych z jednolitego rynku cyfrowego opartych na szybkim i bardzo szybkim Internecie oraz interoperacyjnych

${ }^{22}$ http://www.europarl.europa.eu/sides/getDoc.do?pubRef=-//EP//TEXT+REPORT+A7-2012-0374+ 0+DOC+XML+V0//PL, dostęp: 6.01.2015.

23 B. Piskorska, op.cit., s. 134.

24 Komunikat Komisji do Parlamentu Europejskiego, Rady Europejskiej, Komitetu Ekonomiczno-Społecznego i Komitetu Regionów, http://eurlex.europa.eu/LexUriServ/LexUriServ.do?uri=COM:2010:0245: FIN:PL:PDF, dostęp: 6.01.2015. 
aplikacjach $^{25}$. W założeniach Europejskiej Agendy Cyfrowej znajduje się dostęp wszystkich Europejczyków do szerokopasmowego Internetu do 2013 r., gwarancja dostępu do o wiele szybszego Internetu, o przepustowości przekraczającej $30 \mathrm{Mb} / \mathrm{s}$, do 2020 r., a dla przynajmniej połowy europejskich gospodarstw domowych - o przepustowości przekraczającej $100 \mathrm{Mb} / \mathrm{s}^{26}$.

Mimo wielu starań ze strony Unii Europejskiej nie wszystkie pomysły przedstawione zarówno w Europejskiej Agendzie Cyfrowej, jak i Strategii Unii na rzecz dyplomacji cyfrowej w polityce zagranicznej zostały zrealizowane. Nie powstał również żaden całościowy akt prawnie wiążący, który regulowałby kwestie e-dyplomacji na poziomie europejskim. Jednak podejmowane przez instytucje działania powinny w przyszłości wprowadzić nową jakość do polityki zagranicznej UE.

\section{Dyplomacja cyfrowa UE w praktyce}

Dyplomację tradycyjną zwykło się postrzegać przez pryzmat tworzenia stałych misji dyplomatycznych, takich jak ambasady czy poselstwa jednego państwa akredytowane w drugim państwie. Natomiast Konwencja wiedeńska o stosunkach dyplomatycznych z 1961 r. wymienia podstawowe funkcje dyplomatyczne, do których można zaliczyć:

- reprezentowanie państwa wysyłającego w państwie przyjmującym,

- ochronę interesów państwa wysyłającego i jego obywateli w państwie przyjmującym,

- prowadzenie rokowań z władzami państwa przyjmującego,

- działanie na rzecz rozwoju przyjaznych stosunków między dwoma państwami,

- zaznajomienie się z wszelkimi legalnymi sposobami i warunkami panującymi w państwie przyjmującym,

- możliwość wypełnienia funkcji konsularnych ${ }^{27}$.

Jednak niektórzy autorzy, analizując obecne narzędzia, za pomocą których działa dyplomacja, uznają przedstawione funkcje za nieadekwatne do współczesnych realiów.

Zasadne $\mathrm{w}$ takim razie jest zadanie pytania, jak w praktyce działa dyplomacja cyfrowa i czy spełnia ona wszystkie z wyżej przedstawionych funkcji. Na potrzeby niniejszego artykułu analizie zostanie poddana jedynie e-dyplomacja UE.

Publiczna dyplomacja UE jest rozumiana jako działalność prowadzona przez poszczególne instytucje Unii Europejskiej, a nie jako kompilacja działań państw

25 Komunikat Komisji do Parlamentu Europejskiego, Rady Europejskiej, Komitetu Ekonomiczno-Społecznego i Komitetu Regionów.

26 http://europa.eu/rapid/press-release_MEMO-10-200_pl.htm, s. 4, dostęp: 6.01.2015.

27 B. Surmacz, op.cit., s. 28. 
członkowskich $^{28}$. Dlatego do prowadzenia e-dyplomacji w imieniu UE kompetentni są jedynie jej przedstawiciele. Może ona prowadzić do powstawania nowych instytucji. Wykorzystywanie narzędzi, jakie daje e-dyplomacja, powinno być głównym zadaniem powołanych do tego celu podmiotów, jednak w wielu wypadkach jest to jedynie bierna adaptacja. Zmiany, które przynosi dyplomacja cyfrowa nie zawsze związane są stricte z polityką zagraniczną. Unia Europejska zgodnie z przyjętą przez siebie strategią jest jednym z promotorów wieloaspektowego zarządzania cyberprzestrzenią, wykorzystując do tego celu instrumenty e-partycypacji występujące w relacjach międzynarodowych. Powstała po traktacie lizbońskim dyplomacja europejska w swoich działaniach zewnętrznych wykorzystuje internetowe narzędzia, do których można zaliczyć m.in. blogi, Twittera, virtual reality. Unia Europejska dąży do stworzenia jednolitej dyplomacji cyfrowej, która ma być lekiem na problem reprezentacji Unii na zewnątrz.

UE prowadzi aktywną działalność w mediach społecznościowych, tj. na Facebooku, LinkedIn, YouTube'ie, Twitterze, Daily Motion, MySpace czy Blipie. Przez ostatnie kilka lat aktywność Unii Europejskiej i jej instytucji w dziedzinie dyplomacji cyfrowej znacznie wzrosła. Prowadzona była ona zwłaszcza w ramach dyplomacji publicznej i działań informacyjnych wszystkich instytucji odpowiedzialnych za działania zewnętrzne UE ${ }^{29}$. Dyplomacja cyfrowa Unii Europejskiej jest prowadzona w ramach poszczególnych departamentów Komisji Europejskiej oraz Europejskiej Służby Działań Zewnętrznych, od niedawna kierowanej przez Fredericę Mogherini. Jej poprzedniczka na stanowisku Wysokiego Przedstawiciela ds. polityki zagranicznej i bezpieczeństwa Catherin Ashton była bardzo często krytykowana ze względu na opieszałość swoich działań oraz brak widocznego zaangażowania, także w dziedzinie e-dyplomacji. Na chwilę obecną trudno w jakikolwiek sposób oceniać działalność nowej szefowej unijnej dyplomacji, ponieważ sprawuje ona swoją funkcję stosunkowo krótko, jednak jej obecność w mediach społecznościowych jest widoczna, co dobrze rokuje na przyszłość ${ }^{30}$. Na Tweeterze Mogherini komentuje i dzieli się przemyśleniami związanymi z oficjalnymi spotkaniami, w których uczestniczy. W przeciwieństwie do swojej poprzedniczki jest obecna również na Facebooku, gdzie ma 21832 lajki³1.

Politykę dyplomacji cyfrowej wprowadzają zwłaszcza departamenty Komisji Europejskiej odpowiedzialne za politykę rozwojową, bezpieczeństwa, praw człowieka i inne aspekty zarządzania Internetem, zalicza się do nich zwłaszcza: DG RELEX, DG

\footnotetext{
28 B. Piskorska, op.cit., s. 127.

29 Ibidem, s. 128.

30 https://twitter.com/federicamog, dostęp: 6.01.2015.

31 https://www.facebook.com/f.mogherini?fref=ts, dostęp: 6.01.2015.
} 
Enlargement, DG Agriculture, DG Commerce czy DG Development ${ }^{32}$. Ważną rolę w prowadzeniu cyfrowej dyplomacji odgrywają również przedstawicielstwa głównych instytucji UE, tj. KE, PE, Rady UE czy Komitetu Społeczno-Ekonomicznego. Jakimi środkami posługują się te podmioty? Jest ich bardzo dużo, jednak na potrzeby niniejszego artykułu na szczególną uwagę zasługują broszury, ulotki, a także strony internetowe oraz telewizja, którą można oglądać za pośrednictwem sieci. Wszystkie te podmioty oraz ich działania prowadzone są w imieniu Unii Europejskiej, jednak w dalszym ciągu nie wypracowano spójnej strategii, która miałaby na celu działanie długoterminowe. Ponadto nie przeprowadzono do tej pory żadnych badań, które ilustrowałyby, do jakiego grona odbiorców docierają informacje przekazywane przez jednostki UE za pomocą Internetu.

Głównym portalem społecznościowym, w którym zauważalna jest aktywność zarówno poszczególnych instytucji Unii Europejskiej, jak i pojedynczych polityków jest Tweeter. Wpisy na nim dotyczą najczęściej istotnych spraw, które w sposób pośredni lub bezpośredni wywierają wpływ na politykę UE. I tak dla przykładu, Europejska Służba Działań Zewnętrznych ma na swoim koncie już ponad 10 tys. tweetów i ponad 82 tys. obserwujących ${ }^{33}$. Dodatkowo działalność ESDZ zauważalna jest również na YouTube'ie ${ }^{34}$, w serwisie Flickr.com, gdzie zamieszczane są zdjęcia z oficjalnych spotkań ${ }^{35}$, a także na Facebooku (79 970 kliknięć „lubię to”) ${ }^{36}$. Parlament Europejski odnotowuje również bardzo duże zaangażowanie w mediach społecznościowych. $\mathrm{Na}$ tle eurodeputowanych w tym względzie wyróżnia się M. Schaake ${ }^{37}$. Jej zdaniem, kultura może promować wartości demokratyczne, dlatego jedną z jej głównych propozycji jest stworzenie „marki Europa”, która miałaby za zadanie promowanie Unii Europejskiej w świecie ${ }^{38}$.

$* * *$

Rozwój cyberprzestrzeni dał Unii Europejskiej nowy instrument w postaci dyplomacji cyfrowej jako narzędzia do realizacji polityki zagranicznej. Proces ten przyczynił się również do wzmocnienia, a w zasadzie poprawy wizerunku UE w świecie. Dzięki narzędziom e-partycypacji poniekąd rozwiązano problem reprezentacji

32 B. Piskorska, op.cit., s. 130.

33 https://twitter.com/eu_eeas, dostęp: 6.01.2015.

34 https://www.youtube.com/user/EUExternalAction?feature=mhee, dostęp: 6.01.2015.

35 https://www.flickr.com/photos/eeas/, dostęp: 6.01.2015.

36 https://www.facebook.com/EuropeanExternalActionService, dostęp: 6.01.2015.

37 Holenderska eurodeputowana, w Komisji Kultury, Mediów, Edukacji, Młodzieży i Sportu działa w ramach europejskiej agendy cyfrowej, podkreślając rolę kultury i nowych mediów w polityce zewnętrznej UE.

38 B. Piskorska, op.cit., s. 133. 
tej organizacji w kontaktach z innymi podmiotami stosunków międzynarodowych. Mimo dużego zasięgu dyplomacji cyfrowej (głównie dzięki mediom społecznościowym) charakteryzuje się ona brakiem skorygowanych działań, które w znakomitej większości wypadków mają charakter indywidualny i prywatny. Taki stan rzeczy może wynikać z prostego faktu - unijni przedstawiciele mają do dyspozycji obszar działania w postaci Internetu oraz narzędzia, jakimi są media społecznościowe, ale nie posiadają odpowiedniego zaplecza merytorycznego jeżeli chodzi o e-dyplomację, co z kolei w dużej mierze wynika z niedojrzałości zarówno elit politycznych, jak i europejskiego społeczeństwa. W kwestii polityki zagranicznej pojawia się także problem zgodności działań podejmowanych przez dyplomatów za pomocą Internetu z ogólnie przyjętą strategią państwa. Dwie wyżej wskazane kwestie w znakomitej większości wypadków nie są ze sobą współmierne.

Kolejnym ważnym czynnikiem jest zaplecze prawne dotyczące cyberdyplomacji. Przedstawiciele Unii Europejskiej z całą pewnością zdają sobie sprawę, jak istotną rolę we współczesnym świecie odgrywa cyberprzestrzeń, czego dowodem jest powołana do życia Strategia Unii na rzecz dyplomacji cyfrowej w polityce zagranicznej oraz Europejska Agenda Cyfrowa, jednak brak jest konkretnych aktów prawnych, które w sposób jednoznaczny opisywałyby procedury związane z kontaktami dyplomatycznymi w Internecie.

Mimo wielu zalet, jakie niesie ze sobą prowadzenie działalności dyplomatycznej w cyberprzestrzeni, pojawia się także wiele zagrożeń. Jednym z nich jest chociażby problem wiarygodności zamieszczanych informacji oraz brak pewności (ze strony odbiorców) co do nadawcy wiadomości. Przyczyną takich wątpliwości są popularne obecnie ataki hakerskie. Kolejną kwestią w kontekście Unii Europejskiej jest problem niespójności prowadzonych działań. Dzieje się tak ze względu na brak jednego podmiotu, który zajmowałby się tą kwestią od początku do końca.

Rozwój dyplomacji cyfrowej wprowadza z całą pewnością nową jakość do współczesnych stosunków międzynarodowych. E-dyplomacja nie może być jednak alternatywą dla tradycyjnych działań dyplomatów, chociażby ze względu na potrzebę realizowania misji dyplomatycznych, dzięki którym podtrzymywane są relacje między partnerami dyplomatycznymi. Co więcej, do dziś istnieje głęboko zakorzenione przekonanie, że człowiekowi jako istocie stadnej nic nie jest w stanie zastąpić kontaktów z żywymi ludźmi w rzeczywistym świecie, również w dziedzinie polityki zagranicznej. 


\section{Bibliografia}

Chrzanowski I., Historia literatury niepodległej Polski, Warszawa 1922.

Czaputowicz J., Polityka zagraniczna i dyplomacja Unii Europejskiej, Warszawa 2010.

Frelek R., Najkrótsza historia dyplomacji, Warszawa 2000.

http://ec.europa.eu/eurostat/documents/2995521/6343581/4-16122014-BP-EN.pdf/b4f07b2a-

$-5 a e e-4 b 91-b 017-65 b c b 6 d 95 d a a$

http://eeas.europa.eu/index_pl.htm

http://eurlex.europa.eu/LexUriServ/LexUriServ.do?uri=COM:2010:0245: FIN:PL:PDF

http://europa.eu/rapid/press-release_MEMO-10-200_pl.htm

http://www.epc.eu/prog_details.php?cat_id=6\&pub_id=2790\&prog_id=3

http://www.europarl.europa.eu/portal/pl

http://www.europarl.europa.eu/sides/getDoc.do?pubRef=-//EP//TEXT+REPORT+A7-2012-

0374+0+DOC+XML+V0//PL

http://www.pcformat.pl/Pliki-w-chmurze,a,2539

http://www.uniaeuropejska.org/europejska-sluzba-dzialan-zewnetrznych

https://plus.google.com/+europeanparliament/posts

https://twitter.com/eu_eeas

https://twitter.com/federicamog

https://www.facebook.com/EuropeanExternalActionService

https://www.facebook.com/f.mogherini?fref=ts https://www.flickr.com/photos/eeas/

https://www.linkedin.com/groups/European-Parliament-4157950

https://www.youtube.com/user/EUExternalAction?feature=mhee

https://www.youtube.com/user/EuropeanParliament

Kosienkowski M., Piskorska B., Dyplomacja cyfrowa, Lublin 2014.

Ociepka B., Dyplomacja publiczna, Wrocław 2008.

Snow N., Taylor P., Routledge Handbook of Public Diplomacy, New York 2009.

www.new.org.pl/1157,post.html 